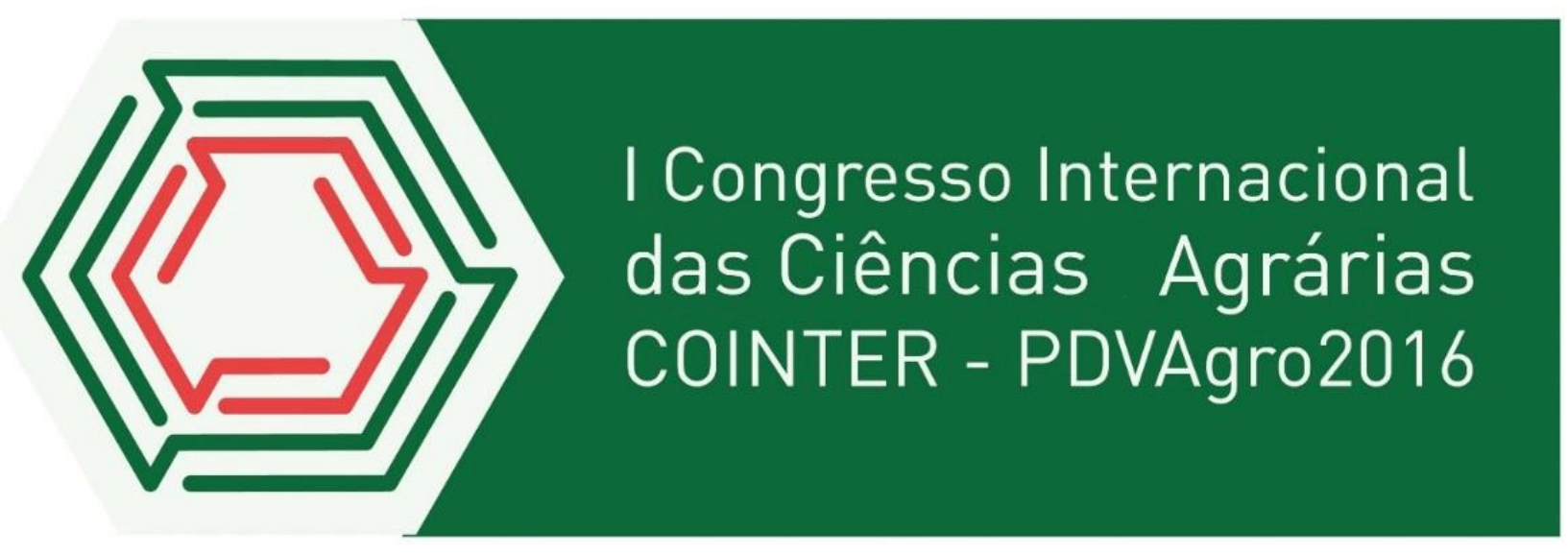

\title{
RELATO DE ESTAGIO SUPERVISIONADO NA FABRICAÇÃO DE BIOFERTILIZANTE
}

Apresentação: Relato de Experiência

\begin{abstract}
Marailze Pereira dos Santos ${ }^{1}$; Leonardo Silva Pontes ${ }^{2}$; Viviane Marques Santos ${ }^{3}$; Lidiane
\end{abstract} Marques Santos ${ }^{4 ;}$ Marcos Barros de Medeiros ${ }^{5}$

\section{Introdução}

Os biofertilizantes são compostos líquidos produzidos por fermentação anaeróbica através da interação de microrganismos, água, estercos ou resíduos vegetais. Possui quase todos os macros e micronutrientes que as plantas necessitam para seu melhor desenvolvimento, além de ser um defensivo natural contra pragas e doenças. O bom desempenho produtivo da cultura do feijão comum (Phaseolus vulgaris L.) associada à obtenção de novas cultivares com características agronômicas desejáveis vem aumentando com o passar do tempo, essa produção intensiva da cultura do feijão exigi um manejo adequado tanto do solo como para cada fase de desenvolvimento da cultura. É de grande importância analisar os efeitos primários e secundários de biofertilizantes líquidos no desenvolvimento da cultura do feijoeiro, em todas as fases fenológicas, devido à necessidade crescente em razão da escassez de estudos e pesquisas nesta área.

\section{Relato de Experiência}

O estágio foi realizado na clínica fitossanitária, e os experimentos realizados no Setor de Agricultura ambos no Centro de Ciências Humanas, Sociais e Agrárias da Universidade Federal da

\footnotetext{
${ }^{1}$ Curso, Instituição E-mail Agroecologia, UFPB, maraylzepereira@hotmail.com

${ }^{2}$ Curso, Instituição, E-mail Agroecologia, UFPB, leleupontes@hotmail.com ${ }_{3}$ Curso, Instituição, E-mail Agroecologia, UFPB, Vivianemarqueagro@gmail.com ${ }_{4}$ Curso, Instituição, E-mail Agroecologia, UFPB, lidianemarqueagro@gmail.com 5 Titulação, Instituição Doutor, UFPB, E-mail mbmedeiros@hotmail.com
} 
Paraíba - Campus III - Bananeiras (CCHSA/UFPB), no período de março a agosto de 2015. O biofertilizante líquido foi produzido em tambores de plástico de 50 litros (Tabela 1), através do processo de compostagem líquida continua empregada por Medeiros (2006). Nos experimentos utilizaram-se diferentes concentrações com intuito de avaliar qual apresentou melhores resultados quanto ao seu efeito defensivo contra pragas e doenças do cultivar do feijoeiro.

Segundo Medeiros e Lopes (2006), os efeitos do biofertilizante no controle de pragas e doenças de plantas têm sido bem evidenciados. Efeitos fungistático, bacteriostático e repelente sobre insetos já foram constatados.

Imagem 1: Atividade Experimental. Fonte: Própria

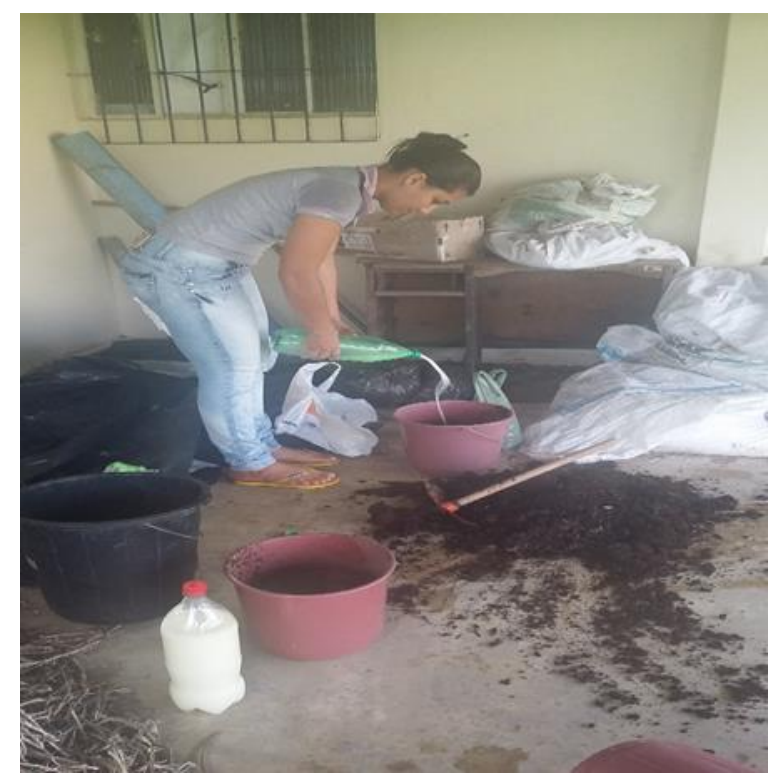

\section{Considerações}

O estágio é uma etapa importante no processo de desenvolvimento e aprendizagem do aluno, porque promove oportunidades de vivenciar na prática conteúdos acadêmicos, além disso, o programa de estágio permite a troca de experiências entre os técnicos, professores e alunos alia conhecimento acadêmico com a experiência vivencial do ambiente de trabalho, porque elucida e complementa na prática os temas abordados nas aulas pelo professor. Assim, o estudante pode reter melhor o conhecimento sobre a profissão escolhida, através da experiência, com isso vim trazendo uma proposta para os agricultores com o intuito de beneficiar a sua produção e de diminuir o uso de insumos químicos na natureza. 


\section{Referências}

ALTIERI, Miguel et al.AGROECOLOGIA: As Bases Científicas da Agricultura Alternativa. 2. ed. Rio de Janeiro: AS-PTA, Assessoria e Serviços \& Projetos em Agricultura Alternativa, 1989. 237 p

BARBOSA, A. S.; MEDEIROS, M.B.. "ORGANALEX": composto enriquecedor para biofertilizantes. Programa Institucional de Bolsas de Iniciação Científica - PIBIC. Universidade Federal da Paraíba. Bananeiras - PB, 2007 